\title{
風荷重を受ける鉄筋コンクリート冷却塔の耐荷力特性 ULTIMATE STRENGTH OF R/C COOLING TOWER SHELLS SUBJECTED TO WIND LOAD
}

\author{
原隆*, 加藤史 郎**, 中村 博 志*** \\ Takashi HARA, Shiro KATO and Hiroshi NAKAMURA
}

\begin{abstract}
The failure mechanisms of the $\mathrm{R} / \mathrm{C}$ cooling tower shells subjected to the dead load and the wind load are examined by use of the finite element method. Also adopting two types of imperfection, bulge type and ring type, the effects of initial imperfections of the ultimate strength of the $\mathrm{R} / \mathrm{C}$ cooling towers are analyzed numerically.

It is concluded that the tension stiffening of the cracked concrete plays the important role to the ultimate strength of the $\mathrm{R} / \mathrm{C}$ cooling tower shells and that the ultimate strength of the hyperbolic $\mathrm{R} / \mathrm{C}$ shells is not sensitive to the initial imperfection.
\end{abstract}

Keywords : reinforced concrete shell, initial imperfection, hyperbolic shell, ultimate strength, cooling tower

鉄筋コンクリートシェル，初期不整，ハイパボリックシェル，耐荷力，冷却塔

1. 序

原子力発電や火力発電の上うな熱交換型の発電施設や 化学プラントでの熱交換のために，水事情の悪い欧米諸 国では自然通風型の大型冷却塔（クーリングタワー）が 多く用いられてきた。近年, 大型冷却塔は巨大化し，高 さ $150 \mathrm{~m}$, 底辺直径 $120 \mathrm{~m}$ 程度のものも作られている。 このような冷却塔は壁厚が形状寸法に比べて極端に薄 く, 來屈に対する安全性の照査は重要な問題である。冷

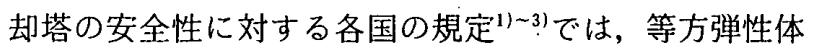
としての弾性解析や, 実験解析を基本資料とした評価規 準が示されている。

ほとんどの冷却塔は鉄筋コンクリートで作られるため に，製作上の不正確さにより形状初期不整が現れる。こ のような構造は圧縮には強いが, 引張りに対してクラッ クを生じやすい。イギリスでの鉄筋コンクリート冷却塔 の崩壊(4)55以来，シェルの応力分布や終局強度に対する 初期不整やクラックの影響が取り上げられ, 多くの研究 者により解析結果が公表されてきだ1 13)。

Ellinas ら゙は死荷重と風荷重を受けるクーリングタ ワーに関して子午線方向の初期不整の影響を研究してい る。Al-Dabbagh ら ${ }^{81}$ はまた, 周方向の初期不整の影響
を研究している。これらの研究はいずれも軸対称問題の 定式化に基づいて解析を行っている。Kemp ら" は Ardeer タワーの解析を行った。そして, 形状初期不整 が冷却塔の応力性状や必要鉄筋量に及ぼす影響が大きい ことを指摘した。Herzog ${ }^{10), 11}$ は，理論的解析に基づい て冷却塔の終局強度の簡易算定法を研究している。 Mang ${ }^{121}$ は，コンクリートのクラックや鉄筋の降伏のよ うな非線形効果がクーリングタワーの終局強度に及ぼす 影響を解析している。 Mang は解析により, 鉄筋コンク リート冷却塔の耐荷力は, 従来上り行われている固有值 解析では評価することはできず，材料の非線形挙動が支 配的要因であることを結論付けている。Milford ${ }^{137}$ は, コンクリートの引張剛性に注目して終局耐力の算定を 行った。

しかしながらこれらの研究をもとに行われた，鉄筋 コンクリート冷却塔に関するIASS の設計指針1), ASCE-ACI 設計指針 ${ }^{2 i}$, BS $4485^{31}$ の改訂にもかかわら ず，1984 年に強風のために Fiddlers Ferry 火力発電所 のクーリングタワーの崩壊が発生している6 。このよう に多くの研究者により鉄筋コンクリート冷却塔の耐荷力 評価が行われているが;, 風荷重の評価, 材料の特性に関
* 徳山工業高等専門学校土木建築工学科 助教授

** 豊橋技術科学大学第六工学系 教授. 工博

*** 豊橋技術科学大学第六工学系 大学院生・工修
Assoc. Prof., Dept. of Civil Engineering and Architecture Tokuyama College of Technology

Prof., Dept. of Regional Planning Toyohashi Univ. of Technology, Dr. Eng.

Graduate Student, Dept. of Regional Planning Toyohashi Univ. of Technology, M. Eng. 
する不確定な要因など，解明されるべき問題は多いよう に思われる。また，各国の設計指針の耐荷力評価の裏付 けとなる基礎的なデー夕が不足しているようである。

そこで本論文では, 鉄筋コンクリート冷却塔の風荷重 に対する崩壊過程を分析するとともに，形状初期不整が 耐荷力特性に及ぼす影響を分析する。数值解析では, 退 化シェル要素を用いて幾何学的非線形性と材料非線形性 を考慮した有限要素解析を行った。また，解析モデルは Port Gibson タワーを用いた。非線形解析においてはコ ンクリートのクラックの特性を明瞭にするために荷重増 分法のみならず, 剛性の変化点の近傍では変位增分法を 用いて荷重変位応答を求めた。

\section{2. 数値解析上の仮定}

数值解析においては，9節点アイソパラメトリック Heterosis 要素を用いた有限要素解析を行った ${ }^{19)}$ 。ひず みの表示は Green Lagrange ひずみを用い，幾何学的非 線形性を考虑した。また，シェルの厚さ方向の状態の変 化を表示するために積層モデルを採用した。

鉄筋コンクリート構造の有限要素解析においては材料 非線形性の取り扱いが解析結果に大きく影響を及ぼす。 本論文では以下に示す仮定を用いて解析を行った。

\section{1 コンクリートの圧縮挙動}

圧縮領域での任意の応力状態にあるコンクリートに対 して次の四種類の条件を用いて応力状態を定義した。

(1) 降伏条件

コンクリートに関する降伏関数は静水圧の大きさによ り降伏曲面が異なる Drucker Prager の降伏条件をもと に決定する。すなわち, 降伏関数は応力の第一不変量 $I_{1}$ と偏差応力の第二不変量 $J_{2}$ を用いて表示する。

$$
f\left(I_{1}, J_{2}\right)=\left[\beta\left(3 J_{2}\right)+\alpha I_{1}\right]^{1 / 2}=\sigma_{0}
$$

ここで， $\alpha, \beta$ は材料のパラメータであり, 本論文では Kupfer $の$ 実験解析 ${ }^{14}$ をもとに, $\alpha=0.355 \sigma_{0}, \beta=1.355$ とした。また $\sigma_{0}$ は相当応力である。式（1）の降伏曲 面を図一1に示す。

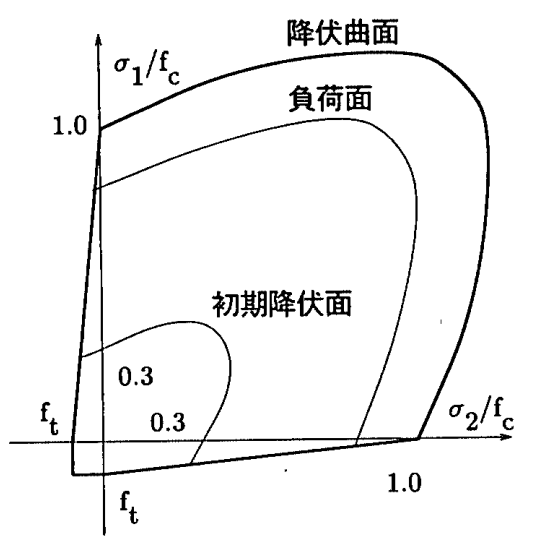

図一1 降伏曲面
（2）流動則

塑性域での応力とひずみの関係式を構成するために Prandtl Reuss の流動則を用いる。

(3) 硬化則

コンクリートの硬化則に関しては次式に示す放物線 (Madrid Parabola) を用いて一軸の応力ひずろ状態と して硬化則を定義する。

$$
\sigma_{0}=-E_{0} \varepsilon_{p}+\sqrt{2 E_{0}^{2} \varepsilon_{c 0} \varepsilon_{p}}: c f_{c}<\sigma_{0}<f_{c} \cdots
$$

ここで, $E_{0}$ は初期弾性係数である。 $\varepsilon_{c 0}=2 f_{c} / E_{0}$ である。 また, $c=0.3$ であり, 最大圧縮強度の $30 \%$ まで, 弾 性状態であることを示す。 $\varepsilon_{\rho}$ は塑性ひずみである。なお， 式（2）に示す硬化則にともなう降伏曲面（負荷面）を 図一1に示す。

\section{（4）コンクリートの圧壊条件}

コンクリートの王壊の判定はひずみ制御で行う。すな わち，降伏曲面の定義式（1）の応力成分をひずみ成分 に置換することにより得ることができる。本解析では, コンクリートの圧壊ひずみ $\varepsilon_{u} を 0.003$ とした。

\section{2 コンクリートの引張挙動}

コンクリートの引張破壊はコンクリートに生じた引張 主応力が引張強度を超えるとき生じるものとする。要素 の特性はクラックが生じる前は等方弾性体として扱う。 そしてクラックが生じた後には要素全体にクラックが生 じるものと仮定し, 要素を直交異方性材料として解析を 行う。二次元の応力状態において, 引張応力は直交する 圧縮応力に影響を受ける。そこで，クラックの発生する 応力規準を次式で示す（図一1 参照)。

引張りー引張領域で

$$
\sigma_{t 0}=f_{t} \cdots
$$

引張り一圧縮領域で

$$
\sigma_{i 0}=f_{t}\left(1+\sigma_{2} / f_{c}\right)
$$

ここで， $\sigma_{i 0}$ はクラック応力である $(i=1,2)$ 。また $\sigma_{2}$ は主引張応力に直角方向の圧縮応力である。 $f_{t}$ は一軸 の引張強度である。

図一2にコンクリートの引張りに対する履歴を示す。 コンクリートは, 式 $(3),(4)$ に示す引張強度 $\sigma_{t}\left(\varepsilon_{t 0}\right)$ に達するまでは弾性の挙動をする。そして, 引張強度を 超えたとき，図に示す経路をたどって応力が低減する。 最終的に引張限界ひずみ $\varepsilon_{m}$ に達したときに完全に引張

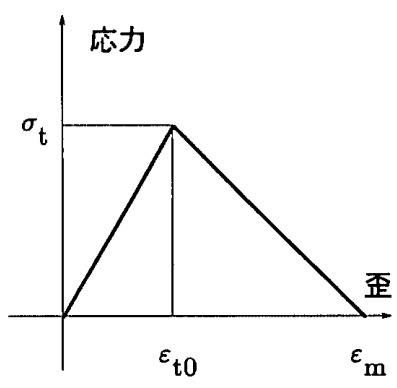

図一2 引張りの履歴曲線 
剛性を失うものとする。引張剛性のパラメータを次式で 定義する。, $\varepsilon_{m}$ の取り扱いは後述する。

$$
\gamma=\varepsilon_{m} / \varepsilon_{t 0}
$$

\section{3 鉄筋の材料特性}

鉄筋は等価な断面積を有する鉄筋シートとして，軸方 向のみに一軸の剛性を有するものとした。鉄筋は圧縮, 引張りとも同様の特性を有するものとし，非線形特性は ひずみ硬化を有するバイリニア型とした。

\section{3. 解析モデル}

\section{1 解析モデルの諸元}

鉄筋コンクリート冷却塔の自重および風荷重に対する 終局耐力に関する初期不整の影響を分析するために， Mang ${ }^{121}$ の解析のモデルとなった Port Gibsonタワーを モデルとした。

図一3に解析に用いたシェルの形状寸法を示す。なお， 幾何形状は次式によって表される ${ }^{12)}$ 。

のビ部より上では,

$$
\begin{array}{r}
-0.0026010 z^{2}-0.038937 r z+r^{2}+1.4174 z \\
-36.7642 r+1278.6678=0 \cdots \cdots \cdots \cdots \cdots(6) .(6) \cdots \cdots
\end{array}
$$

のビ部より下では,

$$
\begin{array}{r}
0.8602 z^{2}+1.4208 r z+r^{2}-51.7196 z \\
-494.4638 r+16674.1904=0 \cdots \ldots \ldots
\end{array}
$$

ここで， $r$ はのよ゙部 $(z=0)$ の上下に测られたシェル 高さ $z[\mathrm{~m}]$ でのシェルの中立面半径 $[\mathrm{m}]$ である。

表一1にシェルの厚さ, 鉄筋位置, 鉄筋量のシェルの

\begin{tabular}{|c|c|c|c|c|}
\hline 座標 $\mathbf{2}[\mathrm{m}]$ & シェル厚 $[\mathrm{cm}]$ & 鉄筋位圈 $\zeta_{\mathrm{t}}$ & $\begin{array}{l}\text { 周方向鉄筋 } \\
\text { 等值孚さ } \zeta_{\mathrm{th}}\end{array}$ & 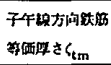 \\
\hline 30.50 & 101.7 & 0.820 & 0.00666 & 0.00207 \\
\hline 23.52 & 20.3 & 0.532 & 0.00351 & 0.00435 \\
\hline-7.26 & 20.3 & 0.532 & 0.00351 & 0.00971 \\
\hline-22.65 & 20.3 & 0.500 & 0.00351 & 0.01191 \\
\hline-38.04 & 20.3 & 0.529 & 0.00450 & 0.01099 \\
\hline-63.24 & 24.0 & 0.590 & 0.00380 & 0.00891 \\
\hline $\begin{array}{r}-88.44 \\
-113.64\end{array}$ & $\begin{array}{l}28.7 \\
34.2\end{array}$ & 0.678 & 0.00364 & 0.00736 \\
\hline-113.04 & 76.2 & 0.812 & 0.00514 & 0.00392 \\
\hline
\end{tabular}
高さに伴う変化を示している。鉄筋位置 $\zeta_{t}$ はシェル中 立面からの鉄筋位置とシェルの板厚寸法の半分の大きさ

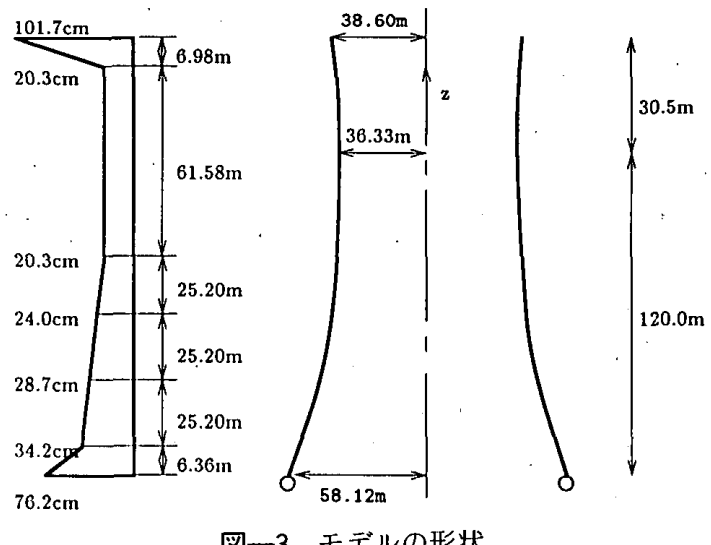

$$
\text { 表一1 シェルの形状 }
$$

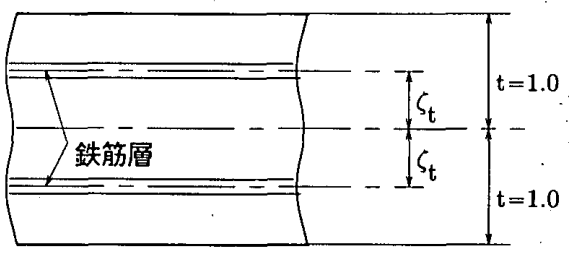

図一4 シェル断面

表-2 材料定数

くコンクリート〉

\begin{tabular}{|l|c|r|}
\hline 弾性係数 & $\mathrm{E}_{\mathrm{c}}$ & $288700 \mathrm{kgf} / \mathrm{cm}^{2}$ \\
\hline Poisson比 & $\nu$ & 0.175 \\
\hline 密度 & $\rho$ & 2.43 \\
\hline 压樎強度 & $\mathrm{f}_{\mathrm{c}}$ & $352 \mathrm{kgf} / \mathrm{cm}^{2}$ \\
\hline 引張り強度 & $\mathrm{f}_{\mathrm{t}}$ & $32.6 \mathrm{kgf} / \mathrm{cm}^{2}$ \\
\hline
\end{tabular}

<鉄筋 >

\begin{tabular}{|l|c|r|}
\hline 弾性係数. & $\mathrm{E}_{\mathrm{s}}$ & $2100000 \mathrm{kgf} / \mathrm{cm}^{2}$ \\
\hline 弾塑性接線係数 & $\mathrm{E}_{\mathrm{t}}$ & $105000 \mathrm{kgf} / \mathrm{cm}^{2}$ \\
\hline 降伏強度 & $\sigma_{\mathrm{y}}$ & $4220 \mathrm{kgf} / \mathrm{cm}^{2}$ \\
\hline 引張り強度 & $\sigma_{\mathrm{u}}$ & $6330 \mathrm{kgf} / \mathrm{cm}^{2}$ \\
\hline
\end{tabular}

の比を示す (図一4 参照)。また, 鉄筋量 $\zeta_{t h}, \zeta_{t m}$ はそれ ぞれ，シェルの内面および外面の二層の鉄筋の一層分に 関する鉄筋量を等洒なコンクリート厚さに変換して示し ている。なおこのモデルの鉄筋量は IASS 設計指針"を 満足している。表一 2 にシェルに用いられたコンクリー トおよび鉄筋の材料特性を示す。

シェルの境界条件は, 基礎部ではピン支持とし, 塔頂 部では自由緣としている。さらに, 荷重, 形状の対称性 を仮定して，タワーを縦方向に二分割し，分割面に対称 の境界条件を設定した。対称面では周方向の回転は拘束 しているが，子午線方向の回転は拘束していない。

図一 5 に冷却塔の $1 / 2$ 解析モデルに対する有限要素 メッシュを示す。メッシュは周方向に 8 分割, 子午線方 向に 12 分割の合計 96 要素である。また，各要素につい て, コンクリートは 8 層に層割を行い, 鉄筋層は 4 層で モデル化した。

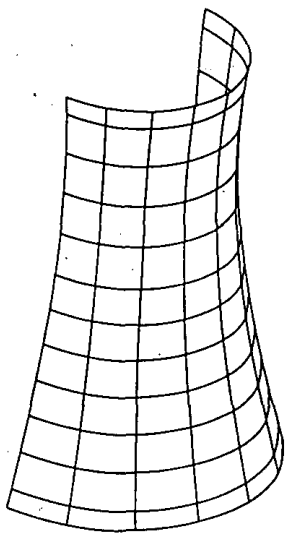

図-5 要素分割 


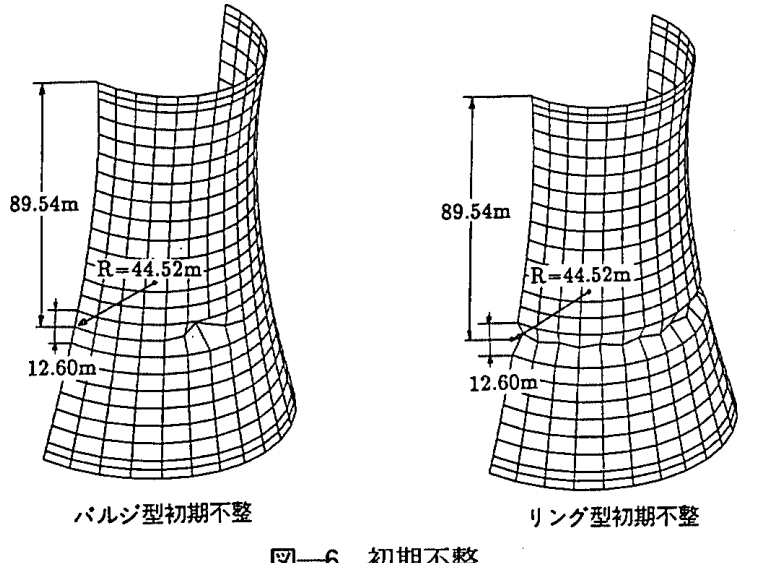

図一6 初期不整

解析したシェルは図一6に示すように二種類の初期不 整を想定している。すなわち，Ardeer タワーの崩壊で 問題とされた，局所的に不整の存在するバルジ型の初期 不整と Fiddlers Ferry タワーの崩壊で問題とされたり ング型の不整である。なお，バルジ型不整については, 図一6に示すように一節点変位で表現した。解析モデル に与えた初期不整の位置は，弾性解析において得られる 座屈形状の最も振幅の大きい部分に設定している。

\section{2 風荷重}

風荷重の分布, 大きさは図一7に示されるように, 種々 の式が提案されている。本論文では比較のために $\mathrm{Mang}^{12)}$ の用いた風力分布係数を用いる。Mang の用い た風力係数分布はBS 4485 の分布に似通っている。な お，図中の分布係数は正の最大值を 1 として規準化して いる。Mang の用いた風力係数は次式で示される。

$$
H_{\theta}=-0.5+\sum_{n=0}^{12} A_{n} \cos (n \theta)
$$

ここで， $\theta$ は風上を基点とする周方向の角度であり, 係 数 $A_{n}$ は表一3に示す值を用いた。なお，Mang の用い た風力係数の最大值は 1.5643 である。また，高さ方向 の分布は次式により示される。

$$
p=42.144 H_{\theta}(3.281 z+393.696)^{2 / 7}
$$

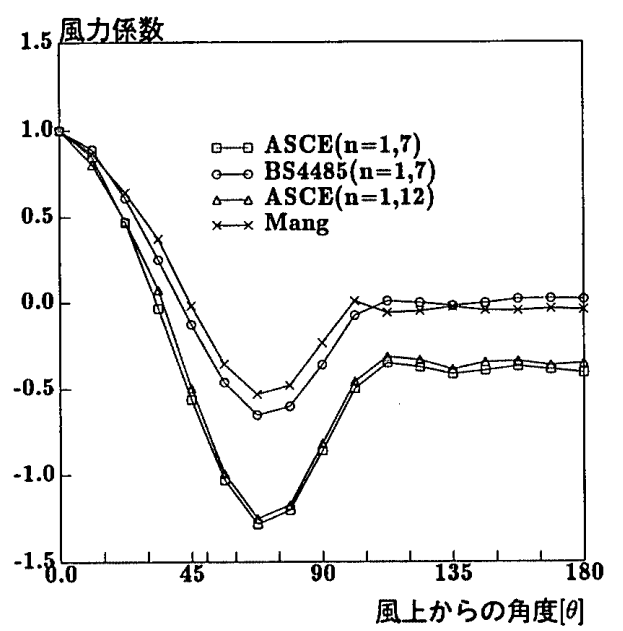

図一7 風圧係数
表一3 風圧係数

\begin{tabular}{|cccc|}
\hline $\mathrm{n}$ & $\mathrm{A}_{\mathrm{n}}$ & $\mathrm{n}$ & $\mathrm{A}_{\mathrm{n}}$ \\
0 & 0.38330 & 7 & -0.04474 \\
1 & -0.27918 & 8 & -0.00833 \\
2 & -0.61978 & 9 & -0.00972 \\
3 & -0.50927 & 10 & -0.01356 \\
4 & -0.09167 & 11 & -0.00597 \\
5 & 0.11794 & 12 & -0.01667 \\
6 & 0.03333 & & \\
\hline
\end{tabular}

ここで, $p$ は風圧 $\left(\mathrm{kgf} / \mathrm{m}^{2}\right), z$ はのどを原点としたクー リングタワーの高さの座標 $(\mathrm{m})$ である。

\section{4. 鉄筋コンクリート冷却塔の耐荷力解析}

風荷重を受ける鉄筋コンクリート冷却塔の崩壊過程を 分析し，また，耐荷力特性に及ぼす初期不整の影響を分 析するために, 数値解析を行う。そして, 得られた結果 と現行の IASS 指針1),16)の関係を考察する。数值解析に おいては, 荷重増分法とともに, Batoz, Dhatt ${ }^{15)}$ の提 案した一点変位増分法を採用した。

\section{1 風荷重を受ける冷却塔の弾性解析}

クーリングタワーに用いられている材料が弾性材であ ると仮定して荷重変位応答を求める。解析において, 変 位増分法を用いて分岐前後の応答特性を求めた。荷重状 態は自重を加えた後に風荷重を加えるものとする。

図一8に風荷重の倍率 $\chi$ を縦軸に, 風上側のど部 $(z$ =0）の半径方向の変位を横軸にして荷重変位関係を示 す。実線は本研究により得られた解析結果である。破線 は Mang ${ }^{12)} に よ り$ 得られた解析結果である。また, 図一 9 に弾性材としてのハイパボリックシェルの変形状態を 示す。状態 (a)，(b)，(c) はそれぞれ図一8の点に相当 している。本解析では図一9の状態（a）から状態 (b) へのモードの明瞭な変化を生じるいわゆる分岐点が存在 する。しかし Mang の解析では分岐点やモード等の詳 細なデータは示されていない。本解析で得られた分岐荷 重は荷重係数 $\chi=21.1$ であり, Mang が固有值解析に

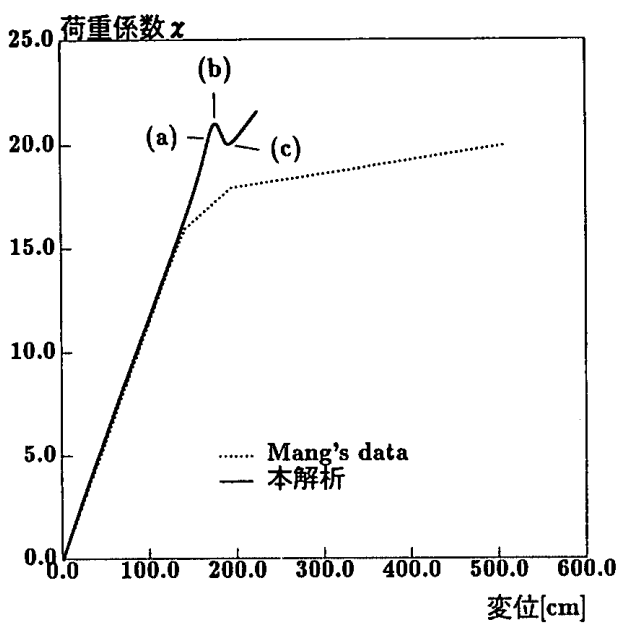

図一8 荷重変位曲線（弾性） 


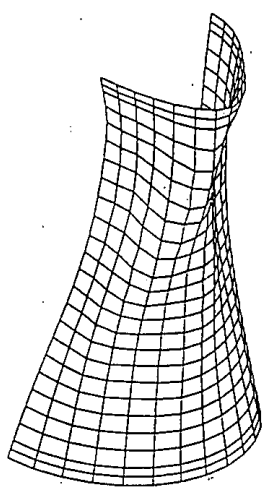

犾態(a)

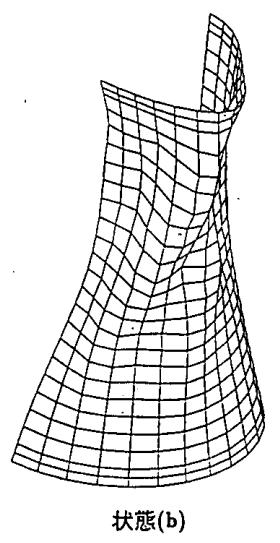

図一9変形形状 (弾性)

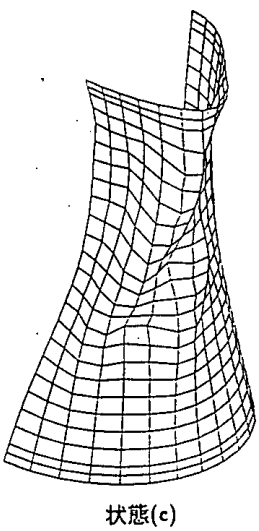

状感(c)
より求めた分岐荷重は $\chi=20.0$ であった。

\section{2 風荷重を受ける冷却塔の応力分布 (弾性解析)}

鉄筋コンクリート冷却塔の耐荷力を分析する基本的な 要因として，風荷重に対する応力分布を求める。応力分 布はシェルの厚さ方向に変化するので, 断面にわたって 積分した断面力の形で表現する。図一10に解析に用い た，各積分点での局所坐標と断面力を符号とともに示す。 図一11に基本風荷重（式（9）参照）の0.2 倍の風 荷重 $(\chi=0.2)$ を受ける場合の断面力の分布を示す。 計算例では自重は考慮していない。また,この荷重レベ ルではコンクリートのひび割れも鉄筋の降伏も生じてい ない。図一11の上図に子午線方向の軸力を示す。子午 線方向軸力は風上側子午線上で引張りを呈し, 風上より 約 $60^{\circ}$ で最大圧縮力を生じている。一方，図一11下図 に示す周方向圧縮力は風上側子午線上では非常に小さく 風上より約 $80^{\circ}$ で最大圧縮力を生じている。

\section{3 風荷重を受ける冷却塔の弾塑性解析}

自重および風荷重を受ける鉄筋コンクリート冷却塔の 終局耐荷力を求める。解析にあたっては，はじめに 5 ス テップに分けて自重を作用させ，変形状態やクラック状 態に特異な変化の生じていないことを確認した後に風荷 重を作用させる。数值計算では Mang ${ }^{12)}$ や Milforrd ${ }^{13)}$ の使用した荷重増分法を用いて解析結果の比較をすると ともに，変位增分法を用いてクラックの発生した後の クーリングタワーの詳細な分析を行った。

（a） 初期クラック発生後の挙動 $(\gamma=1)$

図一12に鉄筋コンクリート冷却塔の弾塑性応答を示 す。解析においてはコンクリートの引張剛性を無視し $(\gamma$ $=1$ 式 (5) 参照), 幾何学的非線形性を考慮して解析

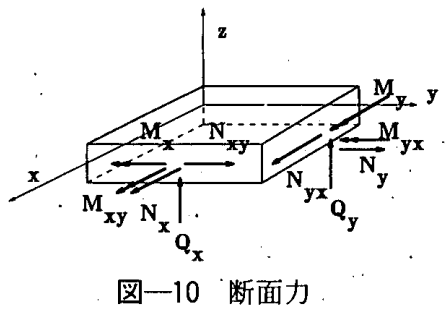

塔頂部 、
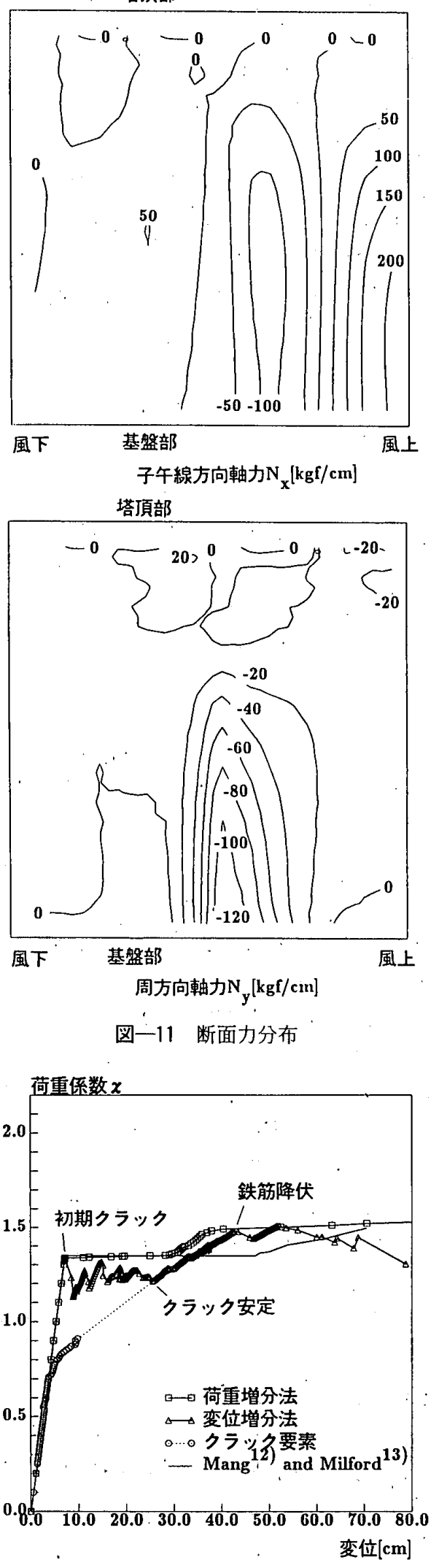

図-12 荷重変位曲線 $(\gamma=1)$

を行った。すなわち，コンクリートは最大引張応力に達. すると直ちに剛性を失う。図に示す変位点は風上子午線 上ののど部から下方に $38 \mathrm{~m}$ の点であり, Mang が解析 において表示した点から $30 \mathrm{~cm}$ 下方の点に相当する。 
すなわち，表示位置による挙動の差異はない。

荷重増分法においては収束の判定は増分変位による等 価節点力の残差のノルムが $1 \%$ 以下になるようにした。 Mang ${ }^{12)}$ の解析結果と比較すると初期クラックの荷重な らびに終局強度はよく一致している。破壊に至るプロセ スとしては，はじめに風上側子午線上の子午線方向の引 張力によりコンクリート表面にクラックを生じる。これ によりシェルは剛性の低下を生じる。しかしながらク ラック後の荷重再分配により子午線方向鉄筋に引張応力 が伝えられ，シェル全体としては崩壊することなくさら に荷重を受け持つことができる。次に引張応力を受ける コンクリート要素に順次クラックが発生した後にクラッ クの進展はほぼ安定する。その後, 子午線方向の鉄筋が 降伏し, 耐荷力を失いシェルは崩壊する。

変位増分法では荷重増分法に対して最も変形の大きい 子午線上ののど部の変位を一点変位制御することより解 析を行った。なお，変位増分法では収束計算を行わず, 残差は次のステップの節点荷重として作用させた。ここ で, 変位増分量はのよ゙部で半径方向に $0.1 \mathrm{~mm}$ と小さい 值を使用し，十分な精度が確保できるように配慮した。

変位増分法では，クラックによる判性の低下が明瞭に 現れている。すなわち, 荷重増分法では平坦部で示され るクラックが進展する領域でクラックの進展にともなっ て荷重の增減が生じている。また, 鉄筋の降伏後の耐荷 力の低下も明瞭に表現することができる。解析結果全体 から見ると, 初期クラック荷重, 鉄筋降伏時の荷重とそ れに引き続く最大耐荷力はほぼ同様であるが, クラック 発生後の耐荷力は変位増分法の方が小さく, 変形能力も 小さく評価されている。

引張剛性が低下した場合のクラック発生後の挙動を調 べるために，特別の要素構成で解析を行う。すなわち， コンクリート断面のクラックが板厚全体に広がって, 剛 性の急激な低下が止まった状態（クラック安定）におい て, クラックの生じた要素すべての引張強度をあらかじ めなくした（実際には引張強度を $1 \mathrm{kgf} / \mathrm{cm}^{2}$ としている） 要素を用いて風荷重を作用させたときの応答を求めた。 解析結果は図一 12 において $\chi=0.7$ から分岐した部分で 示されている。このときの剛性勾配を延長すると, 破線 で示すようにクラック安定点で荷重変位曲線と交わる。 このように，変位増分法による荷重変位曲線のクラック 後に生じるジグザグの勾配はクラックを生じたシェルの 㴊性勾配をそれぞれ表している。このことより，変位増 分法の解析は鉄筋コンクリートシェルの応答を的確に表 現していると思われる。

IASS 設計指針 ${ }^{16)}$ では自重 $D$, 活荷重 $L$, 風荷重 $W$ に対して次式の終局耐荷力を与えている。

$$
U=0.75(1.4 D+1.7 L+1.7 \mathrm{~W})
$$

したがって風荷重に対しては, 設計風荷重の 1.275 倍の
耐荷力を持たなければならない。本解析で用いた Port GibsonタワーはIASS 設計規準を満足しているのでこ れに照らし合わせてみると,クラック荷重は $\chi=1.334$, 終局耐荷力は $\chi=1.530$ といずれも指針を満足してい る。しかしながら, 変位増分解析で得られたクラック進 展の領域では, IASS の規準をやや下回る現象も生じて いる。

(b) 変形およびクラックの性状

図一13に各荷重段階における鉄筋コンクリートシェ ル要素の変形およびクラックの状態を示す。シェルの左 側が風上側の子午線である。

変形に関しては，はじめにシェルは風荷重に片りのよ゙ 部近傍がへこみ，風上側から $60^{\circ}$ 近傍の塔頂部付近では らみだしを生じる。次に荷重の増加とともに風上側子午 線上に水平クラックが生じシェルは折れ曲がる。またこ れにともなって変形はますます増大する。最後にクラッ クの生じた子午線側の要素の子午線方向の鉄筋が降伏 し,これによる変形により,のど部の変形と風上側から $60^{\circ}$ の付近の変形が大きくなり, 風上側子午線上の鉄筋 の降伏の後に, シェルは風上側へ倒壊してゆく。

クラックに関してははじめに風上側子午線上でほぼ水 平に生じている。これは, 図一11に示すように風上側 子午線上で子午線引張力が最大となっているためであ る。荷重の増加とともにコンクリートは外表面において, 風上側子午線上の引張りによるクラックと風上から $60^{\circ}$ 近傍でのはらみだしによる曲げクラックが発生してい る。また，コンクリート内面ではのよ゙部近傍が陥没した ために子午線方向にも周方向にも曲げ引張りが生じ， シェル内表面では二方向のクラックを生じている。

\section{4 コンクリートの引張剛性の影響}

コンクリートの引張剛性の評価は夹験解析を中心にな されている(17)18)。コンクリートの引張㴊性を表すパラ メータとして, 前述の式 (5) に示す $\gamma$ を用いる。 $\gamma$ が大きいとき, クラック後の引張剛性が大きく, 小さい ほど引張剛性は小さい。本論文では Milford ${ }^{13)}$ D研究を 参考にして $\gamma$ を三種類使用する。 $\gamma=1$ は全く引張剛性

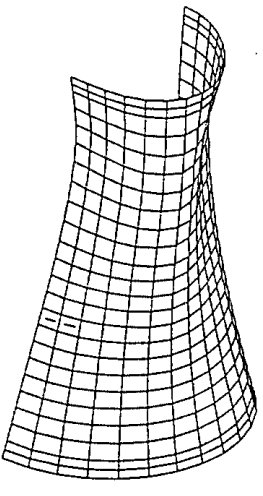

初期クラック時

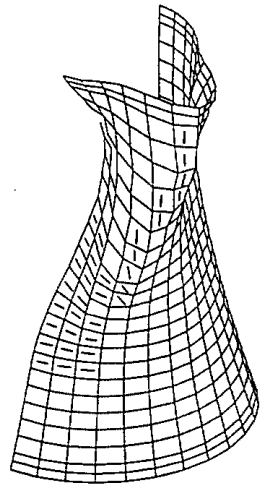

クラック安定時

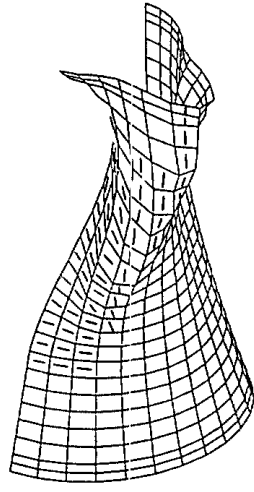

鉄筋榢伏時
図-13 変形形状 $(\gamma=1)$ 
がないモデルである。 $\gamma=5$ は通常の鉄筋量を有する断 面， $\gamma=20$ は非常に引張剛性が大きいモデルである。 (a) $\gamma=1$ の場合

$\gamma=1$ のモデルに対する解析は前項の解析で詳細が示 されている。結果は図-12 に示されている。

(b) $\gamma=5$ の場合

図一14に， $\gamma=5$ に対して得られた荷重変位曲線を示 す。”変位は風上側の子午線上ののど下 $38 \mathrm{~m}$ の半径方向 変位である。クラック時の荷重係数は $\chi=1.335$ である。 また，その時の変位は $7.1 \mathrm{~cm}$ である。

荷重増分法では荷重変位曲線は変位 $11.7 \mathrm{~cm}$ までは 平坦に続く。この領域ではシェル表面にクラックが進展 している。その後荷重変位曲線は増加に転じ, 子午線方 向の鉄筋の降伏が生じた後にシェルは崩壊する。この場 合に終局耐荷力は荷重係数で， $\chi=1.822$ であった。

変位增分法による解析結果は, 図一 12 の場合之同様 に，荷重増分法により得られた初期クラック後の荷重変 位曲線の平坦部分が剛性の変化により負の剛性勾配を有 している。なお，変位増分法により得られたクラック荷

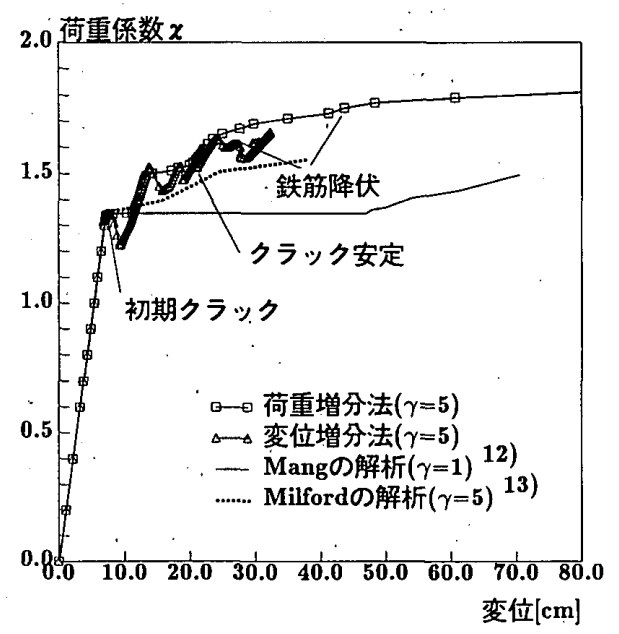

図一14 荷重変位曲線 $(\gamma=5)$

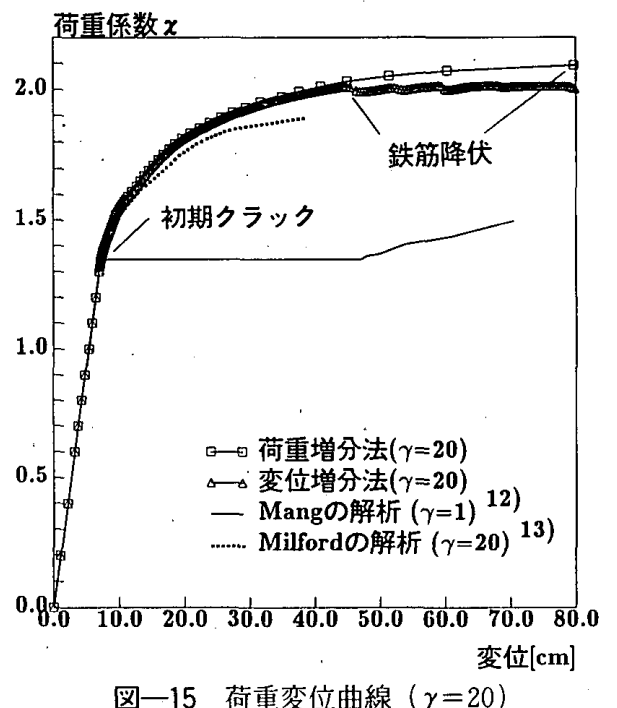

図一15 荷重変位曲線 $(\gamma=20)$
重，終局耐荷力は荷重増分法と同様の結果が得られた。 (c) $\gamma=20$ の場合

図一15に $\gamma=20$ の場合に対する荷重変位曲線を示す。 荷重増分法を用いても引張剛性が大きい場合には図一 12, 図一14 に示すようなクラックによる荷重変位曲線 の平坦部が表れていない。また, 終局耐荷力は三種類の 中で最も大きく， $\chi=2.113$ である。

変位増分法により得られた結果は荷重増分法により得 られた結果とほぼ同様であった。しかしながら, 鉄筋要 素の降伏のはじまりが荷重増分法による解析よりも小さ い変位で生じている。また, 終局耐荷力も $\chi=2.013$ と 若干小さい。

本解析結果と Milford の荷重増分解析結果の比較は以 下のようである。 $\gamma=1$ (図一12）では荷重増分法につ いて解析結果はほぼ一致している。 $\gamma=5$ (図一14) で は荷重増分法によるクラック後の荷重係数の増加傾向が 一致している。 $\gamma=20$ (図一15) については荷重増分法, 変位増分法とも解析結果はほぼ一致している。また引張 剛性の増加は耐荷力の増加となって表れている。これは, 引張剛性による耐荷力の向上とクラックによる応力再配 分による鉄筋応力の増大が抑制されるためであると考え られる。

次に, 初期クラックの生じる積分点に注目して応力状 態を分析してみる。表一4にクラックの生じたコンク リート層の数を荷重係数とともに示す。荷重係数 $\chi=$ 1.334 で初期クラックを生じる。このとき， $\gamma=1$ の材 料に対しては, クラックはコンクリート断面の全断面に 広がっている。また， $\gamma=5, \gamma=20$ の材料に対しては 外側のコンクリート層から内側に向かって全八層のうち 二層のみにクラックが生じている。また, その後の荷重 の増加に対しては $\gamma=20$ のほうが $\gamma=5$ の場合よりも緩 やかにクラックが進展している。このことは, 引張剛性 が大きいほうが応力の再分配が緩やかに行われることを 示している。

\section{5 初期不整の影響}

自重ならびに風荷重を受ける鉄筋コンクリート冷却塔 の耐荷力に及ぼす初期不整の影響を分析する。当該の問 題に関する研究は $\mathrm{Kemp}^{9 /}$ らや Herzog ${ }^{10), 11)}$ により試み られているが軸対称解析により, 材料の等価剛性を用い た近似解法である。著者らの調查した範囲では材料の非

表一4ひび割れ状況

\begin{tabular}{|c|c|c|c|}
\hline 荷重係数 $\chi$ & $\gamma=1$ & $\gamma=5$ & $\gamma=20$ \\
\hline 1.334 & 8層 & 2層 & 2層 \\
\hline 1.338 & 8層 & 4層 & 4層 \\
\hline 1.340 & 8層 & 5層 & 5層 \\
\hline 1.342 & 8層 & 7層 & 6層 \\
\hline 1.344 & 8層 & 8層 & 7層 \\
\hline 1.346 & 8㬝 & 8層 & 8層 \\
\hline
\end{tabular}


線形挙動を考虑して, 局部的な初期不整を忠実に再現し た解析例は見られない。そこで初期不整を有する鉄筋コ ンクリート冷却塔の耐荷力特性を, 荷重変形の関係と応 力分布に注目して解析する。IASS 指針”では初期不整 の振幅の制限を板厚の $1 / 2$ としている。本解析例では制 限値はほぼ $10 \mathrm{~cm}$ に相当する。

図一6にバルジ型とリング型の初期不整を示す。バル ジ型の初期不整量を与える位置は, 図一11において子 午線方向の最大圧縮力を生じる点, すなわち, 高さはの ぞ下 $69.54 \mathrm{~m}$ (塔頂部から $89.54 \mathrm{~m}$ ), 周方向は風上か ら $67.5^{\circ}$ の位置とした。不整の範囲は高さ方向に 12.6 $\mathrm{m}$, 周方向に $17.48 \mathrm{~m}$ とした。また, 初期不整の方向は 図一9を考慮して, 半径方向に内側向きを正とした。リ ング型の初期不整を与える位置はバルジ型と同様に高さ 方向はのど下 $69.54 \mathrm{~m}$ とし, 不整域の範囲は高さ方向 に $12.6 \mathrm{~m}$ とした。

\section{（a）風荷重を受ける冷却塔の応力分布（弾性解析）}

図一 16 に $10 \mathrm{~cm}$ のバルジ不整を与えた場合の断面 力分布を示す。荷重強度は設計風荷重 (式（9）参照)
の 0.2 倍, すなわち, $\chi=0.2$ とし, 自重は作用させて いない。初期不整の影響を考虑しない図一11の断面力 分布に比較して子午線方向軸力は圧縮力がやや大きく なっているものの断面力の乱れはほとんどみられない。 また, 周方向断面力分布については, 子午線方向断面力 よりはその乱れがやや大きい。

図一 17 に $10 \mathrm{~cm}$ のリング不整を与えた場合の断面 力分布を示す。荷重強度は同様に設計風荷重の 0.2 倍と し, 自重は作用させていない。初期不整の影響を考虑し ない図一11 の断面力分布に比較して子午線方向軸力は 圧縮力がやや大きくなっているものの断面力の乱れは小 さい。しかし, バルジ型不整の場合に比べてその乱れは 大きい。また, 周方向断面力分布については, 断面力の 乱れが大きく, 特にリング不整の生じている点の近傍で 曲げ応力の変化に伴う周方向軸力の大きな変動が生じて いる。

\section{（b）風荷重を受ける冷却塔の弾塑性解析}

図一18に自重ならびに風荷重を受ける鉄筋コンク リートシェルのバルジ不整に対する荷重変位曲線を示
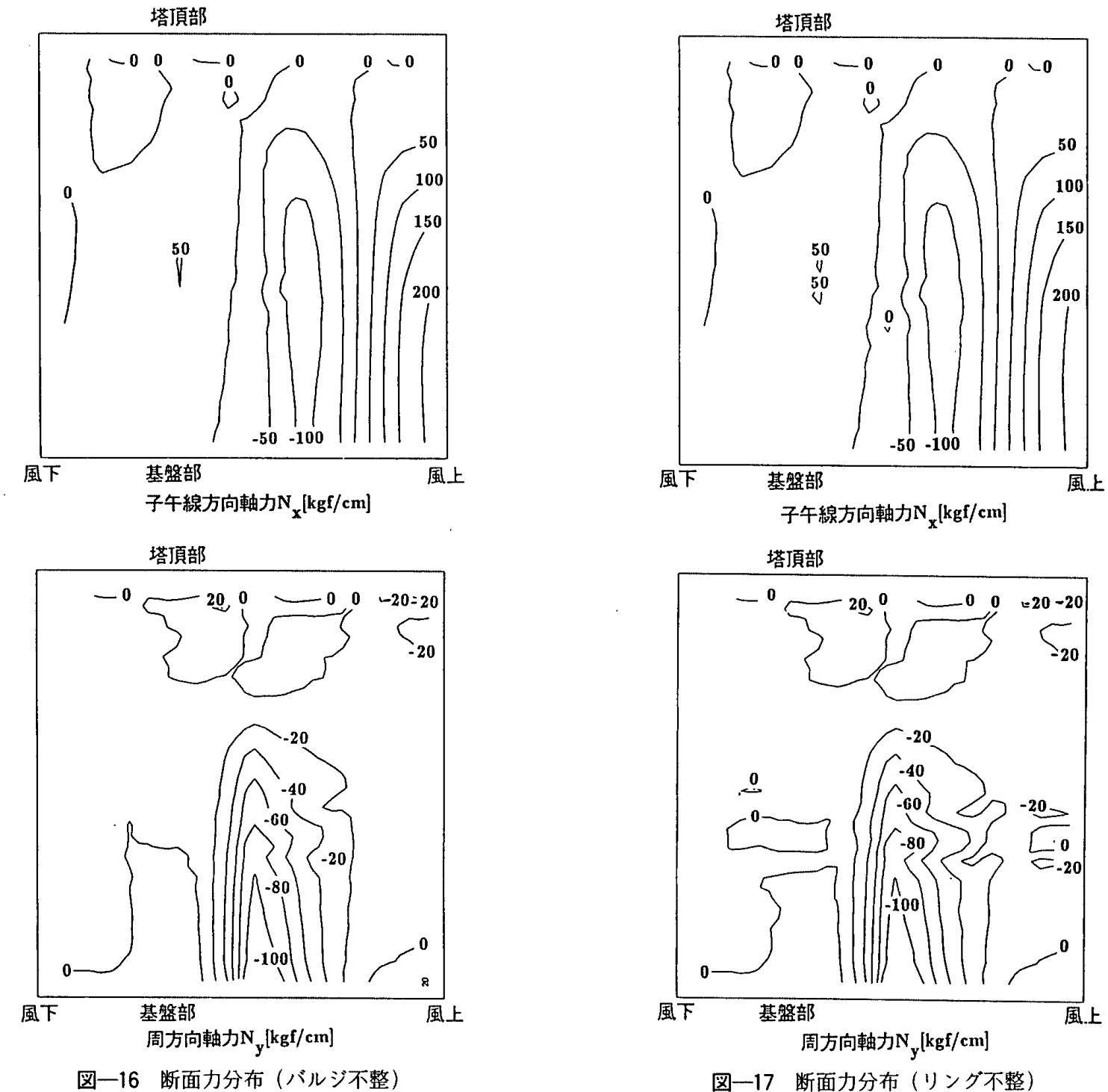


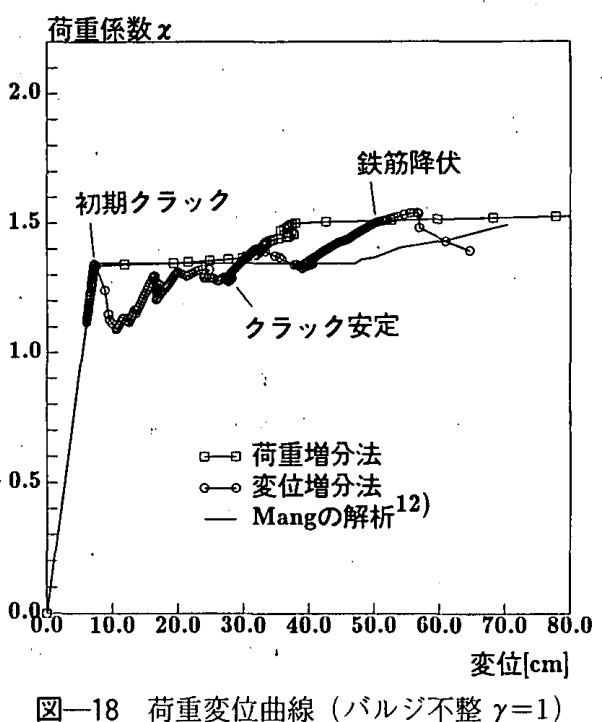

す。バルジ不整は $10 \mathrm{~cm}$ （シェル厚の 0.5 倍に相当）と した。変位点は風上側子午線上ののど下 $38 \mathrm{~m}$ とした。 解析に用いた材料定数は表一2に示すものとし，コンク リートの引張剛性は無視 $(\gamma=1)$ した。荷重増分法に より得られた荷重変位曲線は，初期不整を考慮しない場 合の解析結果（図一12 参照）とほとんど同様である。 また，変位増分法による解析では，初期クラック後の耐 荷力の低下が初期不整のない場合に比べやや大きい。し かしながら鉄筋降伏以後の終局耐荷力は大差がない。こ のことは，断面に鉄筋が十分配筋されているために，断 面にクラックが広がった後は，初期不整がない場合と同 様の挙動をするためであると考えられる。

図一19に自重ならびに風荷重を受ける鉄筋コンク リートシェルのリング不整に対する荷重変位曲線を示 す。リング不整は $10 \mathrm{~cm}$ （シェル厚の 0.5 倍に相当）と した。変位点は同様に, 風上側のど下 $38 \mathrm{~m}$ とした。解 析におけるその他の条件はバルジ不整と同様とした。リ ング不整を有する鉄筋コンクリートシェルの初期クラッ

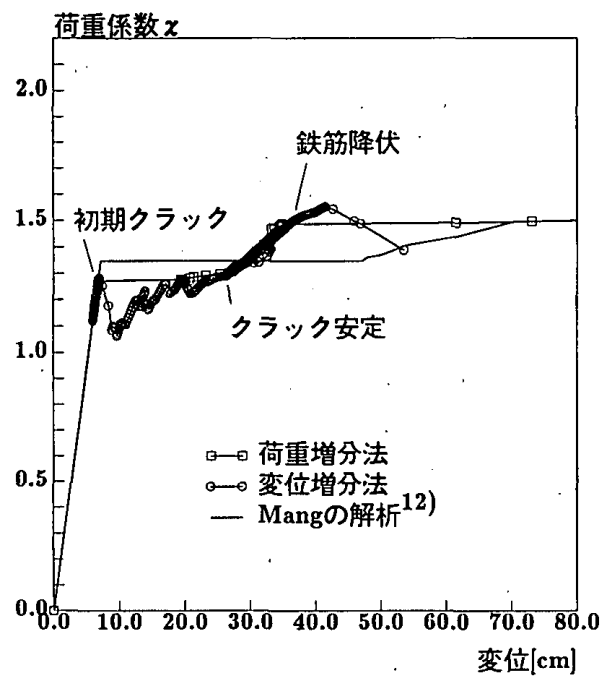

图一19 荷重変位曲線（リング不整 $\gamma=1$ )

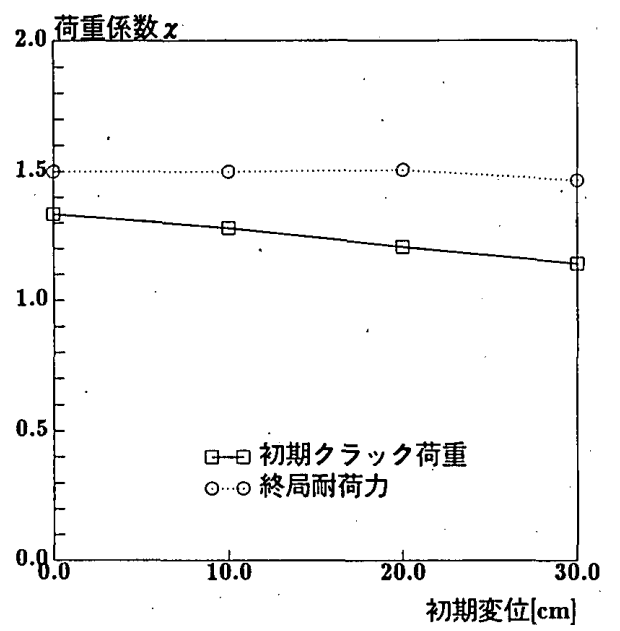

図一20 初期不整と耐荷力（リング不整 $\gamma=1$ )

ク時の荷重は $\chi=1.281$ であり, 初期不整のない場合の 初期クラック時の荷重 $\chi=1.335$ に比べて約 $4 \%$ 小さ い。しかし，終局耐荷力に関しては有為な差異は認めら れない。

図一20にリング型初期不整量の大きさと初期クラッ ク荷重の関係を示す。初期不整が大きいほど初期クラッ クの荷重係数は小さくなっている。初期不整が $30 \mathrm{~cm}$ の場合には約 $15 \%$ の初期クラック荷重の低下が見られ るが, 初期不整が $10 \mathrm{~cm}$ の場合には初期クラック荷重 の低下は約 $4 \%$ である。

鉄筋が十分に配筋された場合にはIASS 指針"の範囲 内では終局耐荷力に影響を与えないので, IASS 指針1” は実用上妥当であるといえる。

\section{5. 結 論}

本論文では自重ならびに風荷重を受ける鉄筋コンク リートシェルの崩壊過程と耐荷力特性に及ぼす形状初期 不整の影響を有限要素法を用いて分析した。分析の結果, 以下の結論を得た。

（1）完全形状の冷却塔の場合，既往の研究201に指摘さ れたように，風荷重に対しては風上子午線上に大きい引 張力が生じ，風上から約 $60^{\circ} \sim 70^{\circ}$ に大きい圧縮力が生 じる。このため，これに対応した子午線方向鉄筋量の配 筋が必要である。

（2）完全形状の冷却塔の弾塑性解析の結果，本解析で 変位增分法により求めた初期クラック荷重ならびに終局

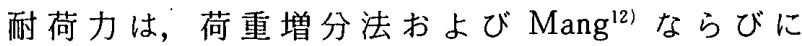
Milford ${ }^{13)}$ により求められた解析結果と一致した。しか しながら，初期クラック後の強度は小さく評価され，ク ラック後のコンクリートの引張強度を無視した解析では IASS 指針16)を下回る場合も生じた。

（3）風荷重を受ける鉄筋コンクリート冷却塔の崩壊過 程は, 風上側のコンクリート面の周方向のクラックに始 まり，変形にともなう風上から $60^{\circ}$ 付近の子午線方向の 
クラックへと広がる。そして，クラックが広がった段階 で，風上側子午線方向の鉄筋の降伏とともに耐荷力を失 い，風上側へ倒壊する。これはFerrybridge の報告"1)に 亦された破壊性状と同様であり, 冷却塔の破壊性状を確 認することができた。

（4）鉄筋コンクリート冷却塔の初期クラック後の耐荷 力挙動に関して，コンクリートの引張剛性の影響を分析 した結果, 引張剛性が小さい場合には初期クラック直後 の耐荷力の低下が著しい。引張剛性が大きい場合には初 期クラック後は耐荷力は漸増する。また, 終局耐荷力は 引張剛性が大きいほど高い。

（5）コンクリートの引張剛性の適切な評価は, 鉄筋コ ンクリート冷却塔の終局耐荷力を適切に評価するために 重要な要因である。

（6）形状初期不整が鉄筋コンクリートシェルの耐荷力 に及ぼす影響を分析した結果，バルジ型初期不整の場合 は断面力の大きな乱れは生じないが, リング型初期不整 の場合には初期不整の近傍で断面力の乱れを生じる。ま た,リング型初期不整を有する鉄筋コンクリート冷却塔 の場合には初期不整が大きくなるほよ゙初期クラック発生 の荷重が小さくなっている。しかしながら, IASS 指針" に示寸初期不整量亡鉄筋量では，終局耐荷力は完全形状 の場合と比較して大きな変化はない。

\section{参考文献}

1) I. A.S.S. Working group No. 3 : Recommendations for the design of hyperbolic or other similarly shaped cooling towers. 1977

2) ACI-ASCE Committee 334 : Reinforced concrete cooling tower shells-practice and commentary. ACI Journal Vol. 74, pp. 22-31, 1977

3) British Standards Institution: Specification for water cooling towers, Part 4. Structural design of cooling towers. 1975

4) Report of the Committee of Inquiry into the collapse of cooling towers at Ferrybridge, Monday 1 November 1965. London Central Electricity Generating Board, August 1966

5) Report of the Committee of Inquiry into the collapse of the cooling tower at Ardeer Nylon Works, Ayrshire on Thursday, 27th September 1973, London : Imperial Chemical Industories Itd., Petrochemicals Division, 1974

6) Report on the Collapse of Cooling Tower B2 at Fiddlers Ferry Power Station on 13 January 1984. Central Electricity Generating Board 1985
7) Ellinas, C.P., Croll, J. G. and Kemp, K. O. : Cooling towers with circumferential imperfections. Journal of the Structural Division, Vol. 106, No. 12, pp. 2405i 2423, 1980

8) Al-Dabbagh, A. and Gupta, A.K. : Meridional imperfection in cooling tower design. Journal of the Structural Division, Vol. 105, No.6, pp. 1089 1102, 1979

9) Kemp, K. O. and Croll, J. G. A. : The rôle of geometric imperfections in the collapse of a cooling tower. The Structural Engineer Vol.54, No.1, pp. 33 37, 1976

10) Herzog M. : Die Tragfäigkeit hyperbolisher Kïhltürme ohne Ringsteifen. Bautechnik Vol.66, No.7, pp.233 238, 1989

11) Herzog M. : Die abgeminderte Tragfäigkeit hyperbolisher Kührtürme mit geometrischen Imperfection. Bautechnik Vol.66, No. 11, pp. 391 394, 1989

12) Mang, H. A., Floegl, H., Trappel, F. and Walter, H. :Wind-loaded reinforced concrete cooling towers: buckling or ultimate load? Engineering Structures Vol. 5, pp. 163 180, 1983

13) Milford, R. V. : Nonlinear behaviour of reinforced concrete cooling towers. Thesis of the Doctor of Philosophy, University of Illinois at Urbana-1984 Champaign The Graduate College 1984

14) Kupfer, H. and Hilsdorf, K. H. : Behavior of concrete under biaxial stresses. ACI. Journal Vol.66., No.8, pp. $656 \sim 666,1969$

15) Batoz, J.L., and Dhatt, G. : Incremental displacement algorithms for nonlinear problems. International Journal for Numerical Methods in Engineering, pp. 1262 1267, 1979

16) The Working Group on Recommendations of I. A.S.S. : Recommendations for reinforced concrete shells and folded plates. 1979

17) Kolleger, J., Gunther, G., und Melhorn, G. : Zug-und Zug-Drukversuche an Stahlbetonscheiben. Forschungsbericht Nr. 1 aus dem Fachgebiet Massivbau, Gesamthochschule Kassel, Universität des Landes Hessen, Kassel, 1986

18) Scanlon, A., Green, D. R., and Phillips, D. V. : Skew reinforced-concrete panels. Journal of Structural Engineering, Vol.117, No. 5, pp. 1477 1491, 1991

19) Hinton, E. and Owen, D. R. J. : Finite Element Software for Plates and Shells. Pineridge Press Limited 1984

20）松岡 理, 加藤史郎, 安田稔邦: 冷却塔の構造特性を中 心にして, 季刊カラム, No. 57, pp. 22 30, 昭和 50 年

(1991 年 9 月 3 日原稿受理, 1992 年 1 月 29 日採用決定) 